\title{
A Study on the Training Model of "Dual system" based on the Mechanism Specialty
}

\author{
Zhu Yu \\ Dalian Vocational \& Technical College Dalian, China. \\ azy-dlvtc@163.com
}

Keywords: Dual system; Double subject; Double standard; Win-win

\begin{abstract}
School enterprise cooperation is the basis of cultivating students in Higher Vocational colleges, At present, the "dual system" talent training mode is booming, This training model not only strengthens the link between schools and enterprises, At the same time, it has a positive significance for the cultivation of Applied Talents in Vocational colleges. This article base on major in mechanical design and manufacturing and GROB Group (Dalian) Co. Ltd. "dual system" joint personnel training, develop a school and enterprise seamless, close communication training program, so as to promote the effective implementation of teaching; enhance students' professional ability and occupation accomplishment, cultivate technical talents for to achieve the win-win goal of enterprises, enterprise.
\end{abstract}

\section{Background}

GROB Group (Dalian) Co. Ltd. is a German owned enterprises , Enterprises in the continuation of Germany's "dual system" of the concept of personnel training and the Institute of "dual system" personnel training cooperation, joint "dual system" talent training in china. The two sides held several rounds of discussions in the scope and way of selecting students, the theory and practice of the curriculum and the content arrangement, teaching methods and patterns, students need to obtain the certificate requirements and other matters, and ultimately to jointly develop the training program of GROB order class talent and the class teaching plan $^{[1]}$. For a period of 3 years and signed a joint cooperation agreement between "dual system" cultivation of talent in July 2013, set up GROB order class in September 2013 .

\section{"Dual System" Personnel Training Curriculum}

School and Enterprise Cooperation to Build Curriculum Objectives. The aim of the course is to construct and realize the interaction between the school and the enterprise in the interaction between the teaching situation and the real workplace environment. In line with the specific position of the enterprise group or the characteristics of a special. In addition, the change of the quantity and mode of practice teaching content and the change of the content of skill operation, the challenge of the previous curriculum objectives. we are more concerned about the students in the two kinds of learning behavior and the operation skills of different situations of interactive learning and practical operation after the change, individual growth and development of students' post migration after the course objectives $^{[2]}$.

"Double Subject" Curriculum Content. Courses in two different teaching situations, two different implementation subject re selection, combination and order, and to comply with the internal logic of the theory and practice of the internal logic of knowledge, make their own system, integration into the whole curriculum system settings also comply with internal rules of skilled talents at the same time the course of the occupation education through talent cultivating. We believe that the class curriculum should reflect between students' cognitive process and work process of the association, the school curriculum and the practice of Enterprise Association, the school curriculum internal relevance, enterprise internal relevancy, school curriculum teaching and enterprise job relevance etc..Therefore, we set up a general curriculum module, professional basic 
knowledge and basic skills courses, occupation quality cultivation curriculum module, job skills curriculum and cultivate students' general basic ability, professional foundation and core competence, occupation quality, post operation. The curriculum system of the main body of the school is reorganized and sorted according to the progressive order of the General basic ability--Vocational basic ability--Basic professional ability-- Professional comprehensive ability

\section{Curriculum Implementation Protection}

Two Alternate Teaching Methods. According to the law of "training mode of dual system requirements and cognitive development of students", I College of the implementation of interactive operation and transformation of school and enterprise, the theory and practice in the teaching process, the teaching mode of double alternate curriculum theory and practice gradually decreasing gradually increasing realizes the integration of teaching, promote the realization of the target of talent training.

In order to meet the needs of the course teaching mode of students alternate wheel, using a variety of teaching methods, the content and objectives of different module courses using different teaching methods. According to the need of teaching, the basic and professional skills courses of the school mainly include teaching, the integration of the theory and practice of the school, the school focused on practical courses. Business courses to practice course and internship course. All general education courses in the enterprise.

Effective Docking of Teaching Standards. Students practice teaching to increase the integration of schools and enterprises to meet the needs of both sides, to meet the needs of AHK vocational qualification training $^{[3]}$. In order to ensure the students practice time in the enterprise, the teaching plan of the class has been revised to promote the school teaching standards and enterprise AHK training standards docking. In addition, students should be awarded by the Ministry of labor and social security and the corresponding professional qualification certificate in the occupation school, to provide the necessary conditions for the future transfer, promote its sustainable development. Enterprises to obtain AHK certificate for the completion of the internship of basic training and target rotation and post.

Equipped with Reasonable Teaching Site. The students alternating between schools and enterprises, schools with specialized classrooms for GROB order class, class layout and cultural construction entirely by students design. According to the German AHK professional standards in strict accordance with the training site and equipment to meet the implementation of the curriculum, enhance students' practical skills.

Teacher Support. School and enterprise select staff composed of teaching team GROB order class dual system of professional. A team of 10 members of the school teaching team, most of them are senior professional and technical titles of the double professional teachers of the backbone of professional teachers; one party members of the teaching team members are technical training engineers or technicians.

Based on school and enterprise cooperation to achieve win-win development. Professional teachers and cooperative enterprises interact frequently, for our holiday, the enterprise provides a "mechanical maintenance" and "machine operation" and "electrical equipment maintenance" three projects of the training of teachers, there are 8 teachers received training.

\section{"Dual System" Personnel Training Management Mechanism}

In order to ensure the teaching content of docking with the organization and implementation of rigor, schools and enterprises in the signing of the agreement on the basis of establishment of modern students' cooperation steering committee composed of the first enterprise engineering and technical personnel, training teachers, school teachers and the class teacher.

Interoperability Mechanism between School and Enterprise. Students in school performance and attendance as well as all the daily activities and learning in the enterprise, the school and the two sides on a regular basis in the form of e-mail feedback information. 
Students' Behavior Norms. Students in the school to comply with the provisions of the "Student Handbook", in the enterprise to comply with the provisions of the apprenticeship manual ${ }^{[4]}$.From the teaching standards, teaching management and the protection of the rights and interests of students and other aspects of the construction of teaching and student management system, so as to enhance the behavior of students.

"Double Standard" Curriculum Evaluation. The development of the personnel training mode of "dual system" has changed, and the curriculum system has changed. Therefore, changes in the evaluation criteria。Schools and enterprises jointly set up the assessment committee, the establishment of enterprise evaluation team, the establishment of enterprise and school "double standard" evaluation system ${ }^{[4]}$. The school is responsible for the evaluation of the effect of the implementation of the theory curriculum in the school, the enterprise is responsible for the evaluation of the effectiveness of the implementation of the project, the enterprise will be the results of feedback to the school, the school is responsible for credit statistics.

Establishment of Management System. The construction of teaching and student management system from the aspects of teaching standards, teaching management and protection of the rights and interests of students. In order to ensure that the school curriculum content and the content of the enterprise curriculum docking, the development of the "GR0B dual orders" teaching implementation management approach and other management system. In order to ensure the connection between school management and enterprise management, the school and the enterprise have formulated the "GR0B dual system order form" student management approach and the "GR0B dual system order form" student subsidy measures, The provisions of the students from the beginning of the school, that is, the school and the management of both sides of the enterprise, the students are both students, but also the enterprise employees, the main identity of students is a student. Enterprises to provide students with a certain amount of monthly living allowance and internship allowance to provide school bus shuttle, reimbursement of student accommodation costs, to add a variety of insurance, in accordance with the enterprise five years of service management ${ }^{[4]}$.

\section{My College’s Characteristics of "Dual System" Training}

My college and GROB Group (Dalian) Co Ltd, embodies the original German "dual system" training mode in Dalian at the same time, the effective implementation of the training mode of "integration of China element dual system of talent ${ }^{[5]}$.

"GROB order class" with "dual system" training implementation in the teaching process of the Post Modernist theory curriculum ,Pay attention to the curriculum of the richness, relevance, circulation and rigor, to achieve the " Three unification ":That is, the unity of the dominant curriculum and the hidden curriculum, the unification of the theory curriculum system and the practice curriculum system, the unification of the enterprise subject curriculum and the school subject curriculum. To a certain extent, it can meet the practical needs of the original "dual system" training mode in Germany, and realize the reform of curriculum system.

\section{Cooperative Outcomes}

Since 2016, two outstanding students have been sent to the German company headquarters for further study.

2014 of the grade Guo Yuchen in the Liaoning Province in the year of the mechanical and electrical equipment installation and debugging skills contest in the first prize in the national skills competition, won the two prize in the.

School of mechanical engineering, 8 teachers participated in the GROB Group Co. Ltd. training, teachers get exercise, modern apprenticeship training teaching level has been further improved.

The provincial and municipal media and the Ministry of education website reported a wide range of innovative achievements of the "dual system" talent training model in our school.

In 2016, the first graduates completed all the courses in school learning. Through the rotation, so that students have a full understanding of their upcoming work environment; by the end of the 
professional practice, to enable students to advance into a working state.2013 of the grade 23 students have graduated and signed an employment agreement with the enterprise

\section{Outlook}

GROB order class course system construction and implementation of the dual subject enterprise, through the AHK occupation open standards in the implementation process, and better teaching standards for docking; Through the establishment of mutual information exchange mechanism between school and enterprise to understand the dynamics of students, the students of a reasonable and effective evaluation; Through the interaction between teachers and trainers, the effective integration of curriculum resources and curriculum resources; Through the understanding of the standard of employment, the promotion of vocational education through vocational education; Through cooperation, we are confident that we will continue to explore cooperation with other enterprises.

\section{Reference}

[1] Jiang Dayuan. The vocational education of dual system vocational education in Germany [J].

China occupation technology education ,2013 (33): 5-14

[2] Sun Junhui. Improvement and exploration of innovative talents training mode in Higher Vocational Colleges and universities [D]. Shandong University, 2012

[3] Tang Zhong, Chen Chunlian, Nie Kun. Discussion on the innovation mode of "dual system" of school enterprise cooperation [J]. Leadership Science Forum, 2015, (21): 31-32

[4] Li Guoyan, Gai Fu, Zhu Yu, and Meng Qing Yun: the. Modern apprenticeship "double wing" professional curriculum system construction and practice of.[J] China occupation technology education 2016 (23): 75-79

[5] Qiu Yongliang. Research on the "dual system" talent training mode of school enterprise cooperation. Education and teaching forum. 2015 (35)

[6] Lin Yuzhen. Study on the application of German dual system teaching mode in Vocational School of route [D] Xiamen: Xiamen University, 2007 